\title{
How to choose a new partner in general practice
}

\author{
Jennifer King, Michael Whitfield
}

\begin{abstract}
Objective-To provide a guide to choosing a new partner in general practice by using psychometric assessments.

Design-A descriptive account of the experience of one practice.

Setting-A general practice in Bristol.

Results-The partners found that using a psychologist to assess both themselves and the candidates facilitated the selection process. During the pre-interview stage the partners learnt about the dynamics of the practice and their own personalities. The examination of the candidates by an outside assessor as well as the partners gave a sense of security and a certainty that mistakes were unlikely to be made.
\end{abstract}

Conclusion-More practices should consider adopting a selection process using psychometric assessments when appointing a new partner.

\section{Introduction}

Methods of recruitment in the NHS vary widely depending on the appointment. The traditional method is by advertisement, application form and letter, references, and interview. In industry selection encompasses a wide range of methods, relying particularly on various psychometric assessments such as psychological aptitude tests and questionnaires. Data from these are intended not to replace the judgment of the interviewer but as an adjunct to the interview, providing a more objective measurement of personal characteristics and allowing candidates to be assessed relative to population norms rather than simply against other candidates. Though we can cite no firm evidence for this approach, the cost of such a selection procedure, if done well, might outweigh the cost of a poor appointment.

The NHS is increasingly using psychometric assessment, particularly when recruiting general managers. Nevertheless, many professional groups are suspicious of these tests and as yet this approach is rarely used when recruiting clinical staff.

General practitioners have tended to use the traditional method of recruiting new partners and trainees. The following procedure is one method of using psychometric assessments to choose a new partner. It is a descriptive account and not an attempt to evaluate the method or to be prescriptive about procedures used in other practices. We have provided a model or guide which can be used and adapted to suit the needs of individual practices.

\section{Methods}

\section{BACKGROUND TO THE RECRUITMENT PROCESS}

The practice is situated in a pleasant inner city area of Bristol. Five partners, three men and two women, look after about 10000 patients. The partners had been appointed by various methods ranging from the traditional shortlist and interviews to appointing a doctor who had had a long term locum appointment. The vacancy had arisen because one of the female partners had resigned.

Having just appointed a practice manager, the partners had been made aware of the difficulties in deciding on the appropriate candidate and decided to seek the advice of a psychologist when appointing the new partner. An advertisement was placed in national and local journals. The advertisement identified the city, stated that the vacancy was for a full time partner in a health centre, and specified that the doctor should be well qualified and caring. A description of the practice was sent to all applicants, and the curriculum vitae of each of the applicants was examined by the partners. At a practice meeting each partner placed the candidates in order of preference. The six receiving the highest positions were selected for the shortlist. A letter was sent to each of these doctors telling them about the selection procedure. Each was invited to visit the practice before the interview, and five of the six agreed to be shortlisted. References were taken up. One candidate withdrew for family reasons.

THE SELECTION PROCEDURE

\section{Analysing the demands of the job}

When more than one person is selecting a candidate each person should have a similar view of the job and the type of person required. Many partnerships reach the decision making stage then find that each partner has different views about the type of person they are looking for so that each judges the candidate against very different criteria. The psychologist, therefore, conducted separate interviews with each partner to identify any diverging opinions about the job and to establish a common set of criteria against which to assess the candidates. Each partner was asked for his or her views on the following: main responsibilities and priorities of the job, particular constraints likely to affect it, key relationships within the practice and health centre, perceptions of the other partners' expectations of the new job, implications of all these for qualifications and experience.

There was general agreement on the main responsibilities, constraints, and critical relationships. There was more divergence on priorities; three main priorities for the new partner emerged from the four partners: clinical safety, good relationships with patients (two partners), producing one or two good new ideas. All partners agreed that they would be trying to decide whether the new partner fitted into the team. After talking to the partners as a group about these differences it transpired that none of the priorities were mutually exclusive and all were equally important.

Assessing the personal qualities required in a new partner

Assessing the personal qualities required in a new partner was the category with the greatest potential for variation in opinion. A common interview bias is to want to recruit people "just like us," but as everyone is 
different this makes agreement on the right candidate impossible. The aim of this stage was therefore to identify the main differences and then to draw up a list of qualities to suit all the partners.

There was considerable agreement over the most important qualities that each principal was seeking in a new partner. The partner was expected to be: organised, flexible, emotionally calm/stable/positive, inquiring/discriminating, assertive but not domineering, innovative, a good communicator at all levels, caring/patient/tolerant, patient centred in his or her approach to treatment, and sharing and sensitive to other partners. There was less agreement over: creativity, intellectual calibre (judged by qualifications and academic record), research interest, marital status (although all agreed that a stable long term relationship was essential).

It was assumed that the female partner would have liked another woman to join the practice, but during group discussions it became apparent that this was not so. She was, however, hoping for the kind of partner who would support her against some of the stronger personalities in the team. This shows how easily assumptions can be made and how they can be mistaken, even in a group of people who work closely together and know one another.

\section{Analysis of team roles}

In any team the mix of personalities has an important bearing on the team's effectiveness. Introducing a new member to the team can enhance or complement its strengths; result in certain strengths becoming overrepresented, thus upsetting the balance of the group; or introduce a weakness into the group so that it stops functioning effectively.

A practice which has difficulties in functioning as a team may find that this affects patient care. They suffer because of, for example, widely differing attitudes among the partners to issues such as smoking or screening. A partner under stress will inevitably communicate stress to his or her patients. One of the implications of the new contract is that doctors should become effective managers. This requires certain attributes which may "make or break" the partnership as a team. Analysing team roles should therefore be an important part of the recruitment process.

The Belbin self perception inventory identifies eight team roles which are essential to the effectiveness of the team, each of which is associated with a particular type of personality.' Considering the importance of a new partner fitting in with the existing team (as in any

TABLE I - Typical features of eight roles identified by Belbin self perception inventory

\begin{tabular}{|c|c|c|c|}
\hline Type & Typical features & Positive qualities & Allowable weaknesses \\
\hline Company worker & $\begin{array}{l}\text { Conservative, dutiful, } \\
\text { predictable }\end{array}$ & $\begin{array}{l}\text { Organising ability, practical } \\
\text { common sense, hard } \\
\text { working, self discipline }\end{array}$ & $\begin{array}{l}\text { Lack of flexibility, } \\
\text { unresponsiveness to } \\
\text { unproved ideas }\end{array}$ \\
\hline Chairman & $\begin{array}{l}\text { Calm, self confident, } \\
\text { controlled }\end{array}$ & $\begin{array}{l}\text { A capacity for treating and } \\
\text { welcoming all potential } \\
\text { contributors on their merits } \\
\text { and without prejudice. A } \\
\text { strong sense of objectives }\end{array}$ & $\begin{array}{l}\text { No more than ordinary in } \\
\text { terms of intellect or creative } \\
\text { ability }\end{array}$ \\
\hline Shaper & $\begin{array}{l}\text { Highly strung, outgoing, } \\
\text { dynamic }\end{array}$ & $\begin{array}{l}\text { Drive and a readiness to } \\
\text { challenge inertia, } \\
\text { ineffectiveness, } \\
\text { complacency, or self } \\
\text { deception }\end{array}$ & $\begin{array}{l}\text { Proneness to provocation, } \\
\text { irritation, and impatience }\end{array}$ \\
\hline Plant & $\begin{array}{l}\text { Individualistic, serious } \\
\text { minded, unorthodox }\end{array}$ & $\begin{array}{l}\text { Genius, imagination, intellect, } \\
\text { knowledge }\end{array}$ & $\begin{array}{l}\text {, Up in the clouds, inclined to } \\
\text { disregard practical details or } \\
\text { protocol }\end{array}$ \\
\hline Resource investigato & $\begin{array}{l}\text { Extrovert, enthusiastic, } \\
\text { curious, communicative }\end{array}$ & $\begin{array}{l}\text { A capacity for contacting } \\
\text { people and exploring } \\
\text { anything new. An ability to } \\
\text { respond to challenge }\end{array}$ & $\begin{array}{l}\text { Liable to lose interest once the } \\
\text { initial fascination has passed }\end{array}$ \\
\hline Monitor-evaluator & Sober, unemotional, prudent & $\begin{array}{l}\text { Judgement, discretion, hard } \\
\text { headedness }\end{array}$ & $\begin{array}{l}\text { Lacks inspiration or the ability } \\
\text { to motivate others }\end{array}$ \\
\hline Team worker & $\begin{array}{l}\text { Socially orientated, rather } \\
\text { mild, sensitive }\end{array}$ & $\begin{array}{l}\text { An ability to respond to people } \\
\text { and to situations and to } \\
\text { promote team spirit }\end{array}$ & $\begin{array}{l}\text { elndecisiveness at moment of } \\
\text { crisis }\end{array}$ \\
\hline Completer-finisher & $\begin{array}{l}\text { Painstaking, orderly, } \\
\text { conscientious, anxious }\end{array}$ & $\begin{array}{l}\text { A capacity for follow up. } \\
\text { Perfectionism }\end{array}$ & $\begin{array}{l}\text { A tendency to worry about } \\
\text { small things. A reluctance to } \\
\text { "let go" }\end{array}$ \\
\hline
\end{tabular}

professional partnership), we tested the existing partners to identify the make up of the partnership in terms of team roles. This would identify any strengths and limitations within the team so that the new candidate (who would also complete the inventory) could be selected accordingly. This questionnaire was used not to show competence as a doctor but as a team member and a person. The typical features of each of the eight roles are shown in table I.

Our team was made up primarily of four key roles based on each partner's perception of himself or herself; these were a shaper, a resource investigator, and two team workers. Hence the team was strong on members who produced good ideas and who made the best possible use of outside resources to pursue them. It was also strong on members willing to listen to other's ideas and to be sensitive to the needs of the group-the ideal complement to the driving but at times less sensitive approach of the shaper.

The analysis of the Belbin questionnaires showed that the partnership could function more effectively if the following roles were introduced. The first was a leader or chairman. One of the partners expressed a strong preference for this role but was rarely allowed to express any leadership qualities because of more dominant forces in the group. The second was a monitor-evaluator, someone who could objectively weigh up all the ideas being generated and evaluated which were worth pursuing. The third was a company worker, someone with good organising ability, with a low level of anxiety, and working primarily for the team rather than through self interest. We agreed, therefore, on the basis of these findings and subsequent group discussion, that the new partner would ideally be someone who would fit the company worker profile-that is, relatively relaxed, working for the good of the group, and with good organisational skills. The monitor-evaluator, while useful for weighing up ideas, was feared to be too introvert and distant because of his or her objectivity and therefore perhaps not the ideal choice for a partner.

\section{Psychometric assessment of the candidates}

The identification of the personal qualities to be assessed determined the choice of personality questionnaires used in the psychometric assessment of the candidate. The following were administered by the psychologist to every candidate as part of the interview:

(1) Belbin self perception inventory (described above).

(2) The Firo B questionnaire determined the ways in which candidates preferred to interact with others. This identified three specific characteristics: affection, control, and inclusion. Scores reflected the extent to which candidates expressed these characteristics and the extent to which they wanted others to display these characteristics towards them. (3) The 16PF questionnaire identified 16 different personality factors designed to reflect attitudes and values. This needed cautious interpretation as some of the factors were more reliable than others. It is particularly useful for identifying anxiety, extroversion/introversion, independence, and assertiveness. It is used clinically to help diagnose a range of mental disturbances including depression, neurosis, and psychosis. It is important to remember that the interview procedure itself can generate anxiety. Any results of this, as with any other questionnaire, must therefore be evaluated with data from an interview.

These questionnaires took about 90 minutes to complete. Apart from the Belbin test, which was self scoring, they had to be scored and interpreted by a trained psychologist. The results were included in a report to the candidate at the end of the recruitment process. 
The extended interview

If supplemented by the information on an application form a well conducted interview can be a powerful selection tool. Interviews can be used to assess certain issues more accurately than others. Communication skills, warmth, or extroversion can often be identified more easily than anxiety or depression; these two are more likely to be identified by psychometric methods.

The interview is potentially subject to several forms of bias. Judgments may be affected by, for example, initial impressions which are resistant to change, "motivated bias" (a tendency to attribute positive qualities to those we like), our mood at the time of interview, stereotypes, or projection (a tendency to condone or condemn traits in others that we perceive in ourselves).

A further problem is that many selectors conduct interviews without a clear or common idea of what is required for success in the job. Because of the team analysis described above with our partnership all four partners were able to draw up a systematic interview plan in advance knowing that they would all be assessing the candidates against similar criteria and standards.

The candidates were given two different interviews. TABLE II-Personal qualities assessed at interview

\section{Quality}

Caring/patience/tolerance Organised

Good comm

Good communicator

Flexibility

Emotional stability/calm/positive

Assertive but not domineering

Commitment

Open/sharing/sensitive to others

Patient centred approach

Innovative

Clinical skills
The first was conducted by the partners and was designed to assess, primarily, medical competence, communication skills, and general attitudes and values on medical care and general practice. The second interview was conducted by the psychologist without the partners being present and was designed to assess personal qualities and to find any potentially sensitive areas of the candidate's background which could have affected his or her performance as a future partner. The qualities assessed in each interview are shown in table II. The candidates were given scores of high, average, or low for each quality.

\section{Making the decision}

The decision was made primarily by the partners, who had each rated the candidates according to the above criteria. The findings from the personality questionnaires and the psychologist's interview were then used to provide more objective data to confirm or question their decision.

The partners were unanimous in their final choice, but the potential risks of the selected candidate were highlighted by the questionnaires and the psychologist's interview and were discussed before a final decision was made.

\section{Discussion}

We have reported this selection process to encourage other practices to consider adopting a similar procedure when appointing a new partner. Having a trained assessor from outside the practice was found to be important as personal questions are always difficult and may be inappropriate to ask in an interview, particularly when the successful candidate is going to join a partnership. The partners found the pre-interview stage valuable, when the various views of the partners were challenged and assessed. They learnt about the dynamics of the partnership and something about their own personalities.

Finally, the examination of the candidates by an outside assessor as well as the partners gave a sense of security and a certainty that mistakes were unlikely to be made. Perhaps all senior clinical staff in the NHS should be appointed in a similar way.

1 Belbin RM. Management teams: why they succeed or fail. London: Heinemann, 1983.

(Accepted 7 September 1990)
There were two grades of consultant in my day: the visiting honorary surgeon in charge of beds, and an assistant surgeon who did outpatient clinics only and had no official beds of his own. Often the assistant was attached to a senior for whom he did the emergency work and often in return he was allowed to have a few beds, perhaps four, in his own name. This meant nothing because many of the other beds in the ward held patients whom the assistant had dealt with in the middle of the night, perhaps for a strangulated hernia, an acute appendix, a perforated duodenal ulcer, and suchlike. This system was a very bad one. Often in the outpatient department the assistant surgeon would see a patient and discuss and suggest treatment, but when the patient was admitted to the ward he saw someone else, who often suggested an entirely different type of treatment. The assistant surgeon, doing so many outpatient clinics, made many contacts with the family doctors and therefore built up quite a large consulting practice, but with only four personal beds he had no place to put the patients referred to him.

There were many nursing homes where patients could be admitted cheaply, but the shortage of personal beds meant that quite a large amount of surgery was done in the patient's own home. As a house surgeon, and later as a registrar, I used to be taken out on many of these trips. It was often to the country and often at night. My job as the junior member was to be the handyman, a sort of jack of all trades. I might be asked to drive the car, often on the way back when my senior wanted a snooze. At the operation I might assist, or give the anaesthetic. This depended on what the general practitioner wanted to do or did not want to do. At the house itself I had to set the scene while my chief was upstairs seeing the patient, and I was responsible for getting the room suitably arranged down belowtaking the flowers off the piano, making a good open space for the kitchen table; one did not do too much disturbing of furniture as this raised the dust, and there was usually a good deal of it available as the place had not been dusted for ages, if ever. I had to make sure there was a free access to hand basins. From all this I learnt a lot, and so when my time came to do this type of surgery I found it not too difficult. (I have happy memories of operating on a strangulated hernia in a cottage close to the water's edge in a small seaside village. There was a knock at the window and I found it was an inquisitive hen wondering what was going on.)

From Blood, Sweat, and Cheers by Ian Fraser. Published under the BMF's Memoir Club imprint. ISBN 072790246 6. Price: Inland f14.95; abroad $£ 17.50$; USA $\$ 29.00$. BMA members: Inland £13.95; abroad £16.50; USA $\$ 27.00$

Every now and then the devil seemed to enter into us and we became a wild, unruly crew. We got drunk at the Café Royal, thrown out of the Chelsea Palace for wolf whistling at the prettiest chorus girl every time she came to the front of the stage on her bicycle, and fought the metropolitan police to the cry of "Have his tonsils." This was permissible since we had a special relationship with the police, as St Thomas's was, and still is, the metropolitan police hospital.

How many of us, I wonder, would have got into medical school if we had had to pass "A" levels? Less than half, I guess. But we were full of vigour and animal spirits. We were out for adventure and we have had it - indeed we are still having it. For sheer achievement, ours may have been bumper years; but on the whole I think not. St Thomas's is a strange and wonderful place. Its intensely conventional excellence seems to draw to it the nonconformists, then to stimulate them to rebel. But such is the intellectual discipline that rebellion is canalised into useful and productive channels. So each year a fresh group of eager youths enter its somewhat dingy portals, a fresh crop of young doctors dutifully pay their subscriptions to the medical defence organisations, and sally forth. Among them are not only the Cuthbert Wallaces and the Percy Sargents but also the Somerset Maughams and the Havelock Ellises of the future. And once every 100 years, I suppose we must expect a Neil Cream. You don't remember him? Well, it is pretty certain that he was in fact Jack the Ripper and there used to be a photograph of him in one of the groups of residents in College House. (This was the collective name for the residents' quarters.)

From A Natural History of Everyday Life: A Biographical Guide for Would-be Doctors of Society by Lord Taylor of Harlow. Published under the BMF's Memoir Club imprint. ISBN 072790242 3. Price: Inland £19.95; abroad $£ 24.00$; USA $\$ 40.00$. BMA members: Inland £18.95; abroad £23.00; USA $\$ 38.00$ 